The Editors of the Proceedings of the Nutrition Society accept no responsibility for the abstracts of papers read at the Society's meetings for original communications.

\title{
PROCEEDINGS OF THE NUTRITION SOCIETY
}

\section{ABSTRACTS OF COMMUNICATIONS}

The Three Hundred and Eighty-first Meeting of the Nutrition Society was held in the Witts Lecture Theatre, Radcliffe Infirmary, Oxford, on Thursday, ${ }_{24}$ February 1983 , when the following papers were read: 
The effect of sucrose feeding and cold exposure on brown adipose tissue of lean and obese Zucker rats. By SuSAN Holt and David A. York, Department of Nutrition, University of Southampton, Southampton $\mathrm{SO}_{3} \mathrm{TU}$

The obese Zucker rat is characterized by an increase in energetic efficiency (Bray \& York, 1979) and deposits excess fat even when pair-fed to lean littermates (Bray et al. 1973). Brown adipose tissue (BAT) function is depressed in ad lib.-fed obese rats (Holt \& York, 1982). The regulation of BAT thermogenesis has been investigated by studying the effect of cold exposure and sucrose feeding on mitochondrial GDP binding.

Five-week-old lean $(\mathrm{fa} / \mathrm{l})$ and obese $(\mathrm{fa} / \mathrm{fa})$ rats were housed either at $24^{\circ}$ or exposed to a $4^{\circ}$ environment for $7 \mathrm{~d}$. Food intake of lean, but not obese, rats was increased by cold exposure. BAT mitochondrial ${ }^{3} \mathrm{H}$-GDP binding was lower in obese rats (mean values $\pm \mathrm{SEM})(\mathrm{I} 67 \cdot 2 \pm 7 . \mathrm{Imol} / \mathrm{mg})$ than lean rats $(260 \pm 4 \mathrm{I} \cdot 9$ $\mathrm{pmol} / \mathrm{mg}$ ) housed at $24^{\circ}$. However, after cold exposure ${ }^{3} \mathrm{H}-\mathrm{GDP}$ binding was increased to similar levels in lean and obese rats $(539.2 \pm 97.2$ and $561.8 \pm 30.9$ $\mathrm{pmol} / \mathrm{mg}$ respectively). The response to cold was, however, impaired in 10-weekold obese rats.

In a second experiment, 5-week-old lean and obese rats were given either chow or chow plus a $30 \%(\mathrm{w} / \mathrm{v})$ sucróse solution ad lib. Gross energy intake was increased in both lean and obese rats drinking sucrose but whereas ${ }^{3} \mathrm{H}-\mathrm{GDP}$ binding to BAT mitochondria was enhanced in lean rats drinking sucrose it was unchanged in obese rats.

These results confirm the suggestion of Rothwell et al. (1982) that the obese Zucker rat has an impaired dietary-induced thermogenesis. Further, they suggest that the defect in BAT thermogenesis in obese rats is a result of impaired regulation in response to dietary factors rather than an impaired capacity of BAT for thermogenesis.

The effect of sucrose on energy intake and BAT mitochondrial GDP binding in lean and obese rats

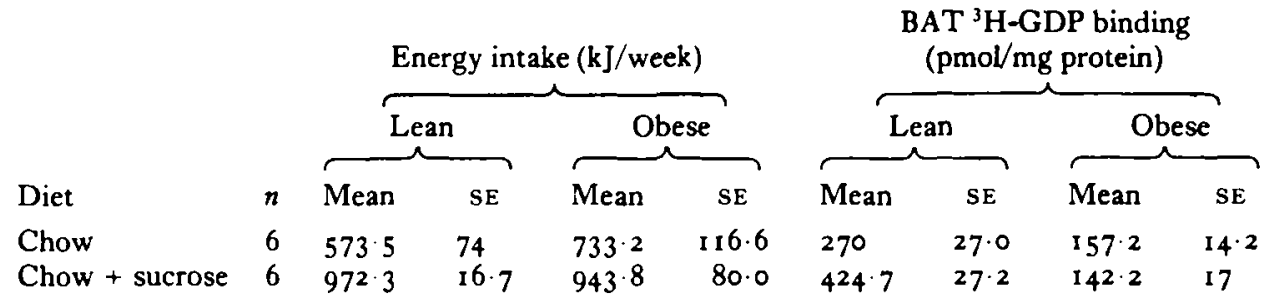

Bray, G. A. \& York, D. A. (1979). Physiol. Rev. 59, 719.

Bray, G. A., York, D. A. \& Swerdloff, R. S. (1973). Metabolism 22, 435.

Holt, S. \& York, D. A. (1982). Biochem. F. 208, 819.

Rothwell, N. J., Saville, E. M. \& Stock, M. J. (1982). Proc. Nutr. Soc. 41, 37A. 
No 'diet-induced thermogenesis' in young lean Zucker rats offered a varied diet. By H. Gillian Barr and K. J. McCracken, Department of Agricultural and Food Chemistry, The Queen's University of Belfast, Newforge Lane, Belfast $B T_{9}{ }_{5} P X$

The most striking example of 'diet-induced thermogenesis' (DIT) in response to cafeteria-feeding is that of Rothwell \& Stock (r982) using young lean Zucker $(+/$ ? $)$ rats. In view of the failure to demonstrate DIT in our laboratory with Sprague-Dawley rats (McCracken \& Barr, 1982) it was decided to extend the study to lean Zuckers and to include a complete pelleted diet of similar nutrient density to the varied or 'cafeteria' diet as an additional treatment.

Thirty male Zucker (+/ ?) rats (Olac $1976 \mathrm{Ltd}$, Oxfordshire) were used. At $130 \mathrm{~g}$ they were allocated to one of four dietary treatments: stock diet ad lib. (PRD, Labsure, Poole, Dorset) S; varied diet including PRD (VL); varied diet including PRD with additional minerals, vitamins and amino acids (VH); high-fat pelleted diet (220 g fat $/ \mathrm{kg} \mathrm{diet)} \mathrm{(HF);} \mathrm{or} \mathrm{slaughtered} \mathrm{for} \mathrm{initial} \mathrm{carcass} \mathrm{composition.} \mathrm{Room}$ temperature was $24^{\circ}$ and rats were caged singly. After 2 I d, S, VL, VH, HF rats were slaughtered and the carcasses analysed for crude protein $(N \times 6.25)$, fat and ash. Metabolizable energy (ME) intake and energy retention (ER) were calculated as described by McCracken \& Barr ( 1982 ).

\begin{tabular}{|c|c|c|c|c|c|c|}
\hline & $\mathrm{S}$ & VL & VH & HF & $\begin{array}{c}\text { SE of } \\
\text { difference }\end{array}$ & $\begin{array}{c}\text { Significance } \\
(P \leqslant)\end{array}$ \\
\hline \multicolumn{7}{|l|}{ ME intake } \\
\hline$(\mathrm{kJ} / \mathrm{d})$ & 249 & 315 & 312 & 287 & 24 & 0.001 \\
\hline$\left(\mathrm{kJ} / \mathrm{d}\right.$ per $\left.\mathrm{kg} \mathrm{W}^{075}\right)$ & 873 & $105 \mathrm{I}$ & 1025 & 963 & 65 & 0.001 \\
\hline$E R\left(\mathrm{~kJ} / \mathrm{d}\right.$ per $\left.\mathrm{kg} \mathrm{W}^{0.75}\right)$ & 146 & 303 & 295 & 235 & 30 & 0.001 \\
\hline $\mathrm{HP}\left(\mathrm{kJ} / \mathrm{d}\right.$ per $\left.\mathrm{kg} \mathrm{W}^{075}\right)$ & 727 & 748 & 730 & 728 & 44 & NS \\
\hline Weight gain $(g / d)$ & $5 \cdot 2$ & $6 \cdot 4$ & $6 \cdot 8$ & 6.0 & $0.5^{8}$ & 0.001 \\
\hline Gross efficiency & 0.17 & 0.29 & 0.29 & 0.24 & 0.020 & 0.001 \\
\hline $\operatorname{IBAT}(\mathrm{g})$ & 0.37 & 0.92 & 0.96 & 0.67 & O. III & 0.001 \\
\hline IBAT ( $\mathrm{g} / \mathrm{kg}$ carcass fat) & $22 \cdot 9$ & $22 \cdot 4$ & $23 \cdot 2$ & $21 \cdot 8$ & 2.61 & NS \\
\hline
\end{tabular}

NS, not significant.

VL and VH treatments increased ME intake, weight gain, energy content of gain, energy retention, gross efficiency and interscapular brown adipose tissue (IBAT) weight $(P<0.00 \mathrm{I})$ compared with treatment $\mathrm{S}$. The HF treatment produced intermediate responses. Heat production (HP) $\left(\mathrm{kJ} / \mathrm{d}\right.$ per $\left.\mathrm{kg} \mathrm{W}^{075}\right)$ was not significantly different between treatments. The large increases in IBAT with VL, $\mathrm{VH}$ and $\mathrm{HF}$ treatments were proportional to the increased body fat content.

These results differ from those of Rothwell \& Stock (1982) in that almost all of the extra ME consumed was converted to body fat and gave rise to significant $(P<0.001)$ increases in growth rate and an improvement in gross efficiency of energy gain. They are consistent with previous reports from our laboratory and with the predicted response of mammals to the consumption of a high-fat diet.

McCracken, K. J. \& Barr, H. G. (1982). J. Physiol., Lond. 330, 69 P.

Rothwell, N. J. \& Stock, M. J. (1982). Br. F. Nutr. 47, 461 . 
Tissue blood flow and oxygen consumption responses to noradrenaline in young domesticated pigs. By L. J. Jamieson, N. J. RothWell", M. J. Stock * and D. Stribling, Bioscience i I, ICI Pharmaceuticals, Alderley Park, Macclesfield, Cheshire SKIO ${ }_{4} T G$ and -Department of Physiology, St. George's Hospital Medical School, Tooting, London $S W_{\mathrm{I}} 7$ oRE

In small rodents, such as the laboratory rat, thermogenic responses to cold, hyperphagia and exogenous noradrenaline are due largely to activation of brown adipose tissue (BAT). The young domesticated pig also raises metabolic rate in response to these stimuli, but was thought to possess no BAT until Dauncey et al. ( 1981 ) identified small quantities of the tissue by light and electron microscopy. In the present study, we have attempted to assess which tissues are responsible for noradrenaline-induced thermogenesis in anaesthetized, young, Large White pigs from measurements of metabolic rate, by indirect calorimetry, and regional blood flow, using radiolabelled microspheres.

Oxygen consumption, corrected for body size $\left(\mathrm{ml} / \mathrm{min}\right.$ per $\left.\mathrm{kg}^{075}\right)$, was similar for pigs aged between 10 and $28 \mathrm{~d}$, but the response to infusion of noradrenaline ( $\mathrm{I} \mu \mathrm{g} / \mathrm{kg}$ per $\mathrm{min}$ ) declined rapidly with age (percentage increases (means $\pm \mathrm{SEM}$ ) after noradrenaline: Io-d-old, $29 \cdot 5 \pm 3 \cdot 3 ;$ 1 4 -d-old, $17 \cdot 6 \pm 1 \cdot 8 ; 28$-d-old, $5 \cdot 5 \pm 0 \cdot 3$ ).

Basal blood flows ( $\mathrm{ml} / \mathrm{min}$ per $\mathrm{g}$ tissue) during saline infusion did not vary significantly with age, and were similar to those reported previously for rats and mice. Infusion of noradrenaline produced moderate increases in blood flow to heart ( $1 \cdot 25$ - to $3 \cdot 3$-fold) and skin (1.3- to $2 \cdot 3$-fold) and decreases in flow to skeletal muscle $(30 \%)$, but had no consistent effects on blood flow to liver, kidney and lung. Average blood flow to four adipose tissue sites (subcutaneous cervical, subcutaneous scapular, axillary and perirenal) increased by 21 -fold in ro-d-old pigs and 9-fold in 14 -d-old and 28 -d-old animals during noradrenaline infusions. Blood flow to adipose tissue during saline infusion was slightly lower in 28-d-old pigs $(0.03+0.008 \mathrm{ml} / \mathrm{min}$ per $\mathrm{g}$ tissue) than 14 -d-old $(0.05 \pm 0.01)$ or ro-d-old $(0.05 \pm 0.03)$ animals. Adipose tissue depots which showed the greatest responses to noradrenaline corresponded to areas where BAT has previously been identified in the pig (Dauncey et al. 1981). For example, the perirenal fat, which appeared brownish in colour, showed a 34 -fold increase in flow during noradrenaline infusion in ro-d-old pigs. The changes in blood flow to adipose tissue also correlated with the rise in $\mathrm{O}_{2}$ consumption during noradrenaline infusion, since both responses declined rapidly with age.

These findings indicate that noradrenaline-induced thermogenesis in the young pig is likely to be due to increased heat production in adipose tissue, and this may be associated with brown fat.

Dauncey, M. J., Wooding, F. B. P. \& Ingram, D. L. (1981). Res. Vet. Sci. 31, 76. 
Thermogenic response to various dietary carbohydrates. By I. MACDONALD and C. Russell, Department of Physiology, Guy's Hospital Medical School, London $S E_{1}{ }_{9} R T$

It has been shown (Benedict \& Carpenter, 1918), and more recently confirmed (Sharief \& Macdonald, 1982), that the thermogenic response to carbohydrates varies with the carbohydrate consumed. Benedict \& Carpenter (1918) suggested that the thermic effect of sucrose, compared with glucose, may be due to the energy released from its hydrolysis to glucose and fructose.

To study whether the energy of hydrolysis of disaccharides is an important factor in carbohydrate thermogenesis, six men were given, after an overnight fast, $2 \mathrm{~g} / \mathrm{kg}$ body-weight of glucose, sucrose, maltose, galactose, lactose, glucosefructose and glucose-galactose ( $\mathrm{I} / \mathrm{g} / \mathrm{kg}$ body-weight of each monosaccharide in the mixes) in $4 \mathrm{ml}$ water/ $\mathrm{kg}$ body-weight. The thermogenic response was calculated for $15-180 \mathrm{~min}$ after ingestion from the oxygen consumption and carbon dioxide output using the ventilated hood technique.

The metabolic rates were similar after ingestion of glucose and maltose, and likewise were similar for sucrose and for the glucose-fructose mixture (Fig. I). The pattern of response was greater when fructose was given, either as sucrose or in the mixture, than after glucose and maltose. The metabolic response to galactose was similar to that of glucose.

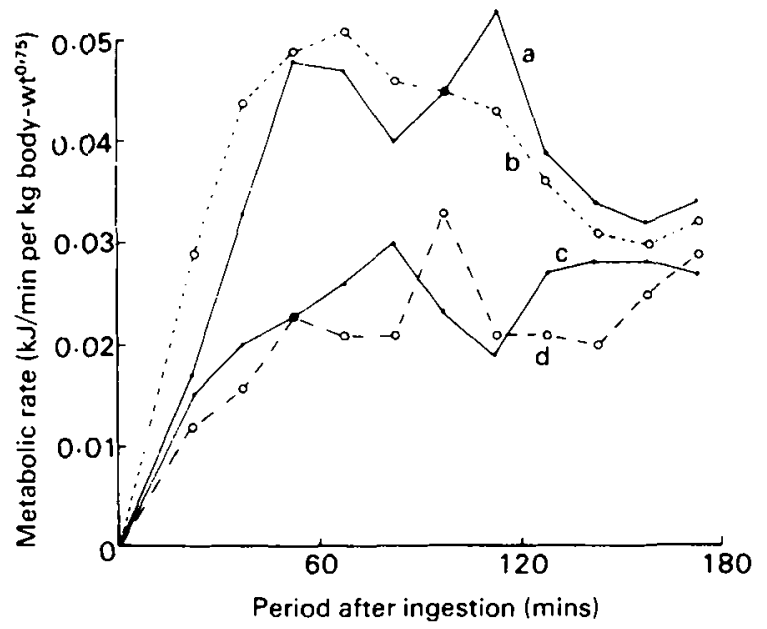

Fig. I. Change in metabolic rate following ingestion of saccharides: (a) sucrose, (b) glucosefructose, (c) glucose, (d) maltose.

The respiratory quotient $(\mathrm{RQ})$ rose steadily throughout the $180 \mathrm{~min}$ with glucose and maltose, but peaked at approximately $60 \mathrm{~min}$ with sucrose and with the glucose-fructose mixture. The RQ after galactose and the glucose-galactose mixture also peaked at approximately $60 \mathrm{~min}$ after ingestion.

Thus it seems that the contribution to the thermogenic response after carbohydrate ingestion of the heat of hydrolysis is small. Also, the high RQs obtained with fructose and with galactose indicate a different metabolic career for these monosaccharides compared with glucose. 
Body-weight regulation in lean and obese rats during pregnancy and lactation. By P. M. van Duljvenvoorde, Barbara J. Rolls and E. A. Rowe, Department of Experimental Psychology, University of Oxford, Oxford $O X_{1}{ }_{3} U D$

During lactation obese rats eating high-energy foods lose substantially more weight than lean, chow-fed rats (Rolls \& Rowe, I982). The following experiment was designed to investigate the influence of body-weight, non-foetal weight gain in pregnancy, and diet on the regulation of body-weight during pregnancy and lactation. One group of female hooded Lister rats was made obese by offering a cafeteria diet containing a variety of high-energy palatable foods (salami, cheese crackers, chocolate chip cookies) and chow for 12 weeks; another group was given just chow. Within these two groups the rats were allocated to four sub-groups, matched for body-weight at mating, which received different diets during pregnancy and lactation (see Table).

\begin{tabular}{|c|c|c|c|c|c|c|c|c|}
\hline & \multicolumn{3}{|c|}{ Pregnancy } & \multicolumn{3}{|c|}{ Lactation } \\
\hline & & & \multirow[b]{2}{*}{ Diet } & \multicolumn{2}{|c|}{$\begin{array}{l}\text { Non-foetal } \\
\text { weight gain (g) }\end{array}$} & \multirow[b]{2}{*}{ Diet } & \multicolumn{2}{|c|}{$\begin{array}{l}\text { Weight change } \\
\text { in } 2 \text { weeks }(\mathrm{g})\end{array}$} \\
\hline & Mean & SEM & & Mean & SEM & & Mean & SEM \\
\hline Lean & $\begin{array}{l}241 \cdot 9 \\
244 \cdot 8 \\
241 \cdot 9 \\
242 \cdot 4\end{array}$ & $\begin{array}{r}7 \cdot 3^{a} \\
10 \cdot 3^{a} \\
8 \cdot 5^{a} \\
8 \cdot 7^{a}\end{array}$ & $\begin{array}{l}\text { Chow } \\
\text { Cafeteria } \\
\text { Chow } \\
\text { Cafeteria }\end{array}$ & $\begin{array}{l}43.0 \\
90 \cdot 5 \\
39 \cdot 2 \\
89.0\end{array}$ & $\begin{array}{l}3 \cdot 7^{a} \\
9 \cdot 3^{b} \\
4 \cdot 4^{a} \\
9 \cdot 0^{b}\end{array}$ & $\begin{array}{l}\text { Chow } \\
\text { Chow } \\
\text { Cafeteria } \\
\text { Cafeteria }\end{array}$ & $\begin{array}{r}11.9 \\
-6.9 \\
17.9 \\
1.1\end{array}$ & $\begin{array}{l}4 \cdot 6^{a, b} \\
8 \cdot 5^{a, c} \\
2 \cdot 4^{b} \\
5 \cdot 5^{a, b, d}\end{array}$ \\
\hline Obese & $\begin{array}{l}324 \cdot 0 \\
324 \cdot 7 \\
323 \cdot 2 \\
323 \cdot 0\end{array}$ & $\begin{array}{r}12 \cdot 1^{b} \\
5 \cdot 0^{b} \\
14 \cdot 2^{b} \\
13 \cdot 2^{b}\end{array}$ & $\begin{array}{l}\text { Chow } \\
\text { Cafeteria } \\
\text { Chow } \\
\text { Cafeteria }\end{array}$ & $\begin{array}{c}22 \cdot 7 \\
100 \cdot 3 \\
31 \cdot 9 \\
99 \cdot 5\end{array}$ & $\begin{array}{c}6 \cdot 9^{a} \\
6 \cdot 3^{b} \\
7 \cdot 3^{a} \\
10 \cdot 9^{b}\end{array}$ & $\begin{array}{l}\text { Chow } \\
\text { Chow } \\
\text { Cafeteria } \\
\text { Cafeteria }\end{array}$ & $\begin{array}{r}-10.8 \\
-54 \cdot 5 \\
3 \cdot 3 \\
-30 \cdot 0\end{array}$ & $\begin{array}{c}5 \cdot 1^{c, d f} \\
7 \cdot 9^{g} \\
11 \cdot 6^{a, b, c} \\
5 \cdot 7^{e f}\end{array}$ \\
\hline
\end{tabular}

Means in the same column which do not share a common superscript are significantly different $P<0.05$.

There was an inverse relationship between the weight gain in pregnancy and the weight change in lactation $(r-0.543, P<0.001)$. Lean and obese rats in comparable groups gained similar amounts of weight in pregnancy, but obese rats either put on less weight or lost more weight during lactation than lean rats. Changing the diet from chow in pregnancy to the cafeteria diet in lactation produced the greatest weight gains during lactation, and changing from the cafeteria diet to chow produced the greatest weight losses in lactation.

There appears to be a regulatory utilization of body-fat stores during lactation which can be affected by pre-existing obesity, non-foetal weight gain in pregnancy, and the diet given in pregnancy and lactation.

Rolls, B. J. \& Rowe, E. A. (1982). Physiol. Behav. 28, 393. 
Maternal inhibition of the immune response to dietary protein in weanling animals: a comparative study of the mouse and rabbit. By JOCELYN Notley, M. J. Gibney and T. G. Taylor, Department of Nutrition, University of Southampton, Southampton SO9 $3 T U$ and P. J. GallaGHER, Department of Pathology, University of Southampton, Southampton $\mathrm{SO}_{9}{ }_{5} \mathrm{NH}$

The capacity of weanling rabbits to develop an immune response to dietary protein is reduced if that protein has been included in the maternal diet, a reduction which may be achieved by either uterine or mammary exposure of progeny to dams given the test protein (Gibney \& Gallagher, I982). Recently, Strobel et al. (198I) have shown that, far from inhibiting subsequent systemic immune response to an intramuscular injection with antigen, pre-exposure of $\mathrm{I}-\mathrm{d}$ old mice to ovalbumin actually enhanced the immune response to ovalbumin injection. On that basis we decided to investigate whether maternal exposure of breeding mice to a protein would inhibit the capacity of their offspring to develop antibodies to that protein in a weanling diet.

Twenty-five rabbits were weaned on to diets based on dried skim-milk (DSM) and forty-two mice were weaned on to ovalbumin-based diets (OVA). Half the rabbits were born of breeding stock exposed to DSM and half the mice were born of stock exposed to OVA. The rabbits were bled and groups of mice killed at regular intervals. Their serum was analysed for anti-OVA Ig $G$ in the case of mice and anti-DSM Ig $G$ in the case of rabbits, both using the enzyme-linked immunosorbent assay. These antibody levels are given in the Table.

Mouse anti-OVA Ig G†

(optical density at $460 \mathrm{~nm}$ )

$\begin{array}{ccccc}\begin{array}{c}\text { Time } \\ \text { after } \\ \text { weaning } \\ \text { (weeks) }\end{array} & \overbrace{\text { No }} & & \text { Mes } & \text { SEM } \\ 0 & 0.18 & * & 1.29 & 0.35 \\ 2 & 1.02 & \text { NS } & 0.90 & 0.41 \\ 4 & 1.03 & \text { NS } & 0.92 & 0.26 \\ 6 & 0.94 & \text { NS } & 0.84 & 0.13\end{array}$

Rabbit anti-DSM Ig G॥ (optical density at $460 \mathrm{~nm}$ )

\begin{tabular}{ccccc}
$\begin{array}{c}\text { Time } \\
\text { after } \\
\text { weaning } \\
\text { (months) }\end{array}$ & \multicolumn{4}{c}{ Maternal DSM exposure } \\
\cline { 2 - 5 } & No & & Yes & SEM \\
2 & 0.03 & NS & 0.02 & 0.03 \\
4 & 0.035 & NS & 0.28 & 0.05 \\
6 & 0.50 & $\bullet$ & 0.19 & 0.05 \\
& 0.53 & $\cdots$ & 0.17 & 0.05
\end{tabular}

Serum dilution: $\dagger_{1}: 20, l_{1}: 200$.

NS, not significant; $* P<0.005$.

Maternal exposure to DSM suppressed the capacity of weanling rabbits to develop anti-DSM Ig G. No such effect was evident with mice. However, mice born of stock not exposed to OVA, developed anti-OVA antibodies to dietary protein much as their rabbit counterparts did with anti-DSM antibodies. Thus, whereas these species behave similarly in the development of the immune response to dietary antigens, they differ in the development of tolerance to these antigens. 
The reliability of the diary and interview method of estimating nutrient intake of children. By D. R. APPLETON ${ }^{*}$, A. F. HACKETT ${ }^{+}$and A. J. RugG-GunN ${ }^{+}$, Departments of "Medical Statistics and +Oral Biology, University of Newcastle upon Tyne, Newcastle upon Tyne NE2 ${ }_{4} B W$

The objective of making any observations on an individual is to gain information and the usefulness of this information depends upon the ability to place an observation of an individual in relation to observations on other individuals and the host population group. One way of quantifying this is through the reliability of the measurement, defined as $\mathrm{I} /\left[\mathrm{I}+\sigma_{\mathrm{e}}^{2} / \sigma_{\mathrm{p}}^{2}\right]$ where $\sigma_{\mathrm{e}}^{2}$ is the error variance of the measurement and $\sigma_{\mathrm{p}}^{2}$ the variance of the measurement in the population to which the individual belongs. Thus, if a measurement does not assign the individual to a narrow range of the distribution of population measurements, because relatively the uncertainty in the measurement is high compared to the spread in the population, the reliability will be low.

A study has been carried out in which 405 Northumbrian children, initially aged I I-I 2 years, completed a 3 d dietary diary plus interview in each of five surveys conducted over a 2 year period. From such a design it is possible to estimate the variability between days, between surveys and between children. In general, if there are $n_{\mathrm{c}}$ children, $n_{\mathrm{s}}$ surveys and $n_{\mathrm{d}}$ days, and the variances associated with each are $\sigma_{\mathrm{c}}^{2}, \sigma_{\mathrm{s}}^{2}$ and $\sigma_{\mathrm{d}}^{2}$ respectively, then the reliability of the estimate of the mean for a child is given by

$$
\sigma_{\mathrm{C}}^{2}\left[\sigma_{\mathrm{c}}^{2}+\sigma_{\mathrm{S}}^{2} / n_{\mathrm{s}}+\sigma_{\mathrm{d}}^{2} / n_{\mathrm{s}} n_{\mathrm{d}}\right]
$$

The reliabilities for daily energy intake, weights of sugars, proteins, fats and carbohydrates in the study were similar $(0.79,0.78,0.78,0.75,0.80$ respectively). The Table shows the percentage reliability for total sugars intake for different combinations of numbers of surveys and days per survey.

$\begin{array}{cccccc}\begin{array}{c}\text { Number of } \\ \text { days per } \\ \text { survey }\end{array} & \overbrace{1} & 3 & 5 & 10 & 15 \\ 1 & 26 & 52 & 64 & 78 & 84 \\ 3 & 42 & 69 & 78 & 88 & 92 \\ 5 & 48 & 74 & 82 & 90 & 93 \\ 7 & 51 & 76 & 84 & 91 & 94 \\ 14 & 56 & 79 & 86 & 93 & 95\end{array}$

It is concluded that the reliability of measuring nutrient intake is higher if the number of surveys is maximized rather than the number of days per survey, and the five survey by $3 \mathrm{~d}$ design was found to be a satisfactory and economical compromise. 
The effect of changes in the amount of dietary protein on the composition of ileostomy fluid. By Fresia Fernandez $Z^{*}$ H. Kennedy ${ }^{+}$, S. Truelove ${ }^{\dagger}$ and M. HILL" (introduced by C. CAYGILL), "Public Health Laboratory Service, Centre for Applied Microbiological Research, Porton Down, Salisbury $\mathrm{SP}_{4} \circ \mathrm{fG}_{\mathrm{G}}$ and + Radcliffe Infirmary, Oxford $\mathrm{OX} 26 \mathrm{HE}$

In previous studies (Cummings et al. 1979) it was shown that an increase in dietary protein from 62 to $132 \mathrm{~g} / \mathrm{d}$ resulted in an increase of faecal protein of $\mathrm{I} \% \%$, a $25 \%$ increase in faecal tryptophan and a $46 \%$ increase in urinary volatile phenol (UVP). There are many possible explanations of these results and so, in order to obtain more information, the effect of the two diets on the composition of ileostomy fluid was determined.

Eleven volunteers with an ileostomy for ulcerative colitis and with no small intestinal disease, after suitable dietary advice, consumed isoenergetic diets containing $40-50 \mathrm{~g}$ protein (LP) or 1 ro- $120 \mathrm{~g}$ protein (HP) for 2 weeks while living at home. At the end of each diet period the volunteers attended the outpatient clinic and samples of ileostomy fluid were taken for bacteriological analysis and a $24 \mathrm{~h}$ collection was taken for chemical analysis. Before the first dietary period similar samples were taken representative of the control diet.

The mean wet weight of ileostomy fluid $(500 \mathrm{~g} / \mathrm{d})$ and the dry weight $(60 \mathrm{~g} / \mathrm{d})$ exceeded the normal faecal mass by factors of 4 and 2 respectively. Change from the LP to the HP diet, representing a $155 \%$ increase in dietary protein, resulted in a $36 \%$ increase in ileostomy protein (assayed by the Lowry method), which was similar to the increase in UVP produced by the same dietary change in persons with a complete colon. The amount of protein in ileostomy fluid (mean \pm SD) on the LP diet was $17 \pm 7 \mathrm{~g} / \mathrm{d}$ and on the HP diet was $23 \pm 7 \mathrm{~g} / \mathrm{d}$; these amounts compared with 8 and $9 \mathrm{~g}$ respectively in faeces of persons on the two diets. Because of the small number of patients none of these differences was statistically significant.

We conclude that the amount of protein reaching the terminal ileum is only qualitatively and not quantitatively related to the amount of dietary protein; more than half of the protein reaching the terminal ileum is further degraded during transit through the colon. Finally, the amount of UVP in urine and of tryptophan in faeces is related more to the amount of protein entering the colon rather than the amount in the diet or faeces.

Cummings, J. H., Hill, M. J., Jivraj, T., Houston, H., Branch, W. J. \& Jenkins, D. J. A. (1979). Am. f. clin. Nutr. 32, 2086. 
Microbiological and oligosaccharide content of ileostomy fluid in subjects taking an unrefined and a refined carbohydrate diet. By S. HORI, M. Hudson and M. Hill $\dagger$, Public Health Laboratory Service, Centre for Applied Microbiological Research, Porton Down, Salisbury $\mathrm{SP}_{4} \circ \mathrm{f}_{\mathrm{G}}$ and Louise Berghouse, Elizabeth Rogers and J. Lennard-Jones, St. Mark's Hospital, City Road, London EC I $2 P S$

An unrefined carbohydrate diet has been recommended for the treatment of Crohn's disease $(C D)$ following dietary surveys which showed that $C D$ patients tend to eat a diet rich in sucrose compared with that eaten by the general population. Studies of ileostomists indicated that compared with control subjects, they tend to eat a diet containing low amounts of dietary fibre. We have analysed the ileostomy effluent in five patients with CD and five with ulcerative colitis (UC) after 2 weeks on a diet rich in sucrose and low in dietary fibre (diet A) compared with the same period on a diet rich in unrefined carbohydrate and containing no sucrose (diet B). Healthy volunteer patients were given appropriate dietary advice and their compliance assessed by a trained dietician. On the last day of each period the patients were given a suitable breakfast containing $(\mathrm{g})$ sucrose $\mathrm{I}_{3} .5$, starch 45 , fibre 2.5 , protein 13.0 and fat 15.5 (diet A) or sucrose 3.5 , starch 47 , fibre 9.5 , protein 14 and fat 16.5 (diet B). Samples of ileostomy fluid were taken at hourly intervals for the next $9 \mathrm{~h}$ for bacteriology using a catheter inserted approximately $100 \mathrm{~mm}$ into the stoma; the total effluent was pooled at hourly intervals for biochemical analysis throughout and, on all tests, $\mathrm{UC}$ and $\mathrm{CD}$ patients behaved similarly.

Breath hydrogen analysis was negative at all times in all patients, indicating that the bacterial flora was sparse and was exposed to the substrate for only a short time. The amount of ileostomy fluid during the $9 \mathrm{~h}$ period was greater on diet $\mathrm{B}$ than on diet $A$, both in terms of wet weight (mean values $\pm \mathrm{SD})\left(23^{8} \pm 89 \mathrm{~g} v\right.$. $162 \pm 79 \mathrm{~g}, P<0.02)$ and dry weight $(23.6 \pm 6.8 \mathrm{~g} v .14 .9 \pm 6.6 \mathrm{~g}, P<0.01)$, possibly explaining why ileostomists choose to eat a diet relatively low in dietary fibre. The amounts of glucose and oligosaccharides in the ileostomy fluid were also greater on diet $\mathrm{B}$ than on diet $\mathrm{A}(\mathrm{I} 69 \pm 4 \mathrm{I} \mathrm{mg} v .82 \pm 25 \mathrm{mg}, P<0.00 \mathrm{I})$ in all ten volunteers; this must represent partially degraded dietary fibre, since it was contrary to the amount of sucrose and starch eaten on the two diets. Bacterial analysis showed that the ileostomy fluid contained $10^{685} \mathrm{organisms} / \mathrm{ml}$ on diet $B$ compared with only ${ }^{10^{5.45}}$ organisms $/ \mathrm{ml}$ on diet $\mathrm{A}$, this difference was observed in all organisms present. The flora was rich in streptococci, enterobacteria, lactobacilli and veillonella but the most important faecal organisms, bifidobacteria and bacteroides, were each only isolated from five patients and regularly from only two patients.

The results of this study do not support any hypothesis of a role for specific bacteria in the causation of inflammatory bowel disease. In particular, the organisms thought to be important from faecal analyses are present in the terminal ileum - the major site of Crohn's disease - in only small numbers, if at all. A major concern of ileostomists is to minimize the amount of ileostomy fluid. The results reported here indicate that a low-fibre diet should be recommended to achieve this.

†For correspondence. 
Intestinal transit times and faecal weights of South Indian subjects. By P. S. SheTty and A. KurPad, Department of Physiology, St. Fohn's Medical College, Bangalore 560034 , India

Although it is generally assumed that intestinal transit time is shorter in people living in the Tropics, compared with the West, data on transit times for tropical subjects, particularly from India, are at best anecdotal. This study was designed to measure intestinal transit times in South Indian subjects on a metabolic diet using standardized methods which are not subject to day-to-day variations in bowel habits.

Fourteen healthy, adult, male South Indian subjects, aged between 18 and 25 years, were admitted to a metabolic ward and maintained on metabolic diets for 24 $\mathrm{d}$. During the initial $8 \mathrm{~d}$ the subjects were equilibrated on individualized metabolic diets which were maintained throughout the rest of the study period. The diet provided constant amounts of energy $(11-12.5 \mathrm{MJ}(2600-3600 \mathrm{kcal}) / \mathrm{d}$ per subject), protein $(60-66 \mathrm{~g} / \mathrm{d})$ and dietary fibre $(3 \circ-40 \mathrm{~g} / \mathrm{d})$ and was a typical South Indian diet, largely rice-based. Mean intestinal transit time (MTT) was then continuously measured for 2 weeks thereafter, using the continuous marker method (Cummings et al. 1976 ).

The mean ( $\pm \mathrm{SD}$ ) MTT of the fourteen subjects was $32 \cdot 3 \pm 8 \cdot 7 \mathrm{~h}$ (range $18.9-46.6 \mathrm{~h}$ ) and the mean faecal weight was $190.7 \pm 57 \cdot 1 \mathrm{~g} / \mathrm{d}$ (range 1 i $7.7-296.5$ $\mathrm{g} / \mathrm{d}$ ). The MTTs were lower than those reported in the West and the mean faecal weights on the upper end of the range of faecal weights seen in the West (i.e.

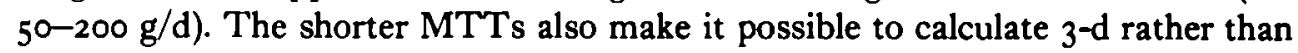
5 -d running means and also imply that shorter periods of equilibration to achieve metabolic balances are indeed justifiable.

Transit times based on the single dose technique ( $80 / 20$ markers) were measured during metabolic balances and again when the same subjects were on ad lib. diets in order to correlate values with those obtained using the continuous marker method. Comparable values obtained indicate that some of the single dose methods may be used for epidemiological studies of MTT in large population groups.

We acknowledge the support received from the Medical Research Centre, Bombay Hospital Trust for this study. Ethical approval was obtained for the study.

Cummings, J. H., Jenkins, D. J. A. \& Wiggins, H. S. (1976). Gut 17, 210. 
Transit times through the human gut of markers taken at different times of the day. By J. C. MAThers, Centre for Tropical Veterinary Medicine, University of Edinburgh, Easter Bush, Roslin, Midlothian EH25 $9 R G$ and J. S. Blake, Department of Applied Biology, University of Cambridge, Pembroke Street, Cambridge $\mathrm{CB}_{2}{ }_{3} D X$

Long transit times of food residues through the gut may be involved in the development of colon cancer and other gut diseases. Frequently, markers have been given only at breakfast and it has been assumed that the transit time of such markers represents that of residues from food eaten throughout the day. We have measured the transit times of markers taken with each of the main meals during a day.

On a Monday, three female and four male subjects, all apparently healthy and aged between 23 and 45 years, each swallowed capsules containing sixty radioopaque markers with each meal; type $R_{1}$ (small rods) were taken during breakfast, $\mathrm{R}_{2}$ (medium circles) during lunch and $\mathrm{R}_{5}$ (large circles) during dinner. All faeces voided throughout that day and for the next $4 \mathrm{~d}$ were collected using devices similar to those of Hinton et al. (1969). Marker output was measured from radiographs of the stools and mean transit time (MTT) for each marker separately and for all three together were calculated as described by Cummings et al. (1976).

Mean daily faecal output ( $179 \pm 9.6 \mathrm{~g}$ ) was relatively high for UK subjects and may reflect higher than usual intakes of dietary fibre. Recovery of markers in faeces was good $(98.3 \%)$ and was similar for the three markers. Mean MTTs $(h)$ were $46 \cdot 4,39 \cdot 2,41 \cdot 7$ and $42 \cdot 5$ ( \pm 0.99 ) for marker types $R_{1}$ (breakfast), $R_{2}$ (lunch), $R_{5}$ (dinner) and all markers respectively. Duncan's multiple range test indicated that MTT for $\mathrm{R}_{1}$ was significantly $(P<0.05)$ longer than that for the other markers. These differences are unlikely to be due to inherent properties of the markers, as Cummings et al. (1976) found no significant differences in MTT between various markers of this kind taken simultaneously.

We conclude that MTT estimated from markers taken at breakfast is not representative of MTT for all meals and that food residues from breakfast stay in the gut longer than those from other meals.

We are grateful to Dr John Cummings, Dunn Clinical Nutrition Unit, for provision of materials and encouragement.

Cummings, J. H., Jenkins, D. J. A. \& Wiggins, H. S. (1976). Gut 1 7, 210.

Hinton, J. M., Lennard-Jones, J. E. \& Young, A. C. (1969). Gut ro, 842. 
${ }^{65}$ Zinc metabolism in coeliac disease. By R. W. Crofton, S. Gvozdanovic, D. Gvozdanovic, P. J. Aggett, N. A. G. Mowat and P. W. Brunt, Departments of Medicine and Biomedical Physics and Bioengineering, University of Aberdeen, Aberdeen $A B 9$ I $F X$

Crofton et al. (1982) have shown that zinc absorption is impaired in untreated coeliac disease, using the oral $\mathrm{Zn}$ tolerance test: this technique measures the absorptive capacity of the proximal small intestine for $\mathrm{Zn}$ in free solution. Using ${ }^{65} \mathrm{Zn}$, we have investigated the absorption of exogenous $\mathrm{Zn}$ and the turnover of endogenous $Z_{n}$ in untreated and treated patients with coeliac disease.

Six patients with untreated and three with partially-treated coeliac disease and five healthy volunteers were studied. Subjects were injected intravenously with $0.25 \mathrm{mg} \mathrm{Zn}$ labelled with $18.5 \mathrm{kBq}(0.5 \mu \mathrm{Ci}){ }^{65} \mathrm{Zn}$. They were followed for 2 months using a whole body counter and $\mathrm{Zn}$ turnover calculated. The subjects then consumed a standard meal which was extrinsically labelled with $92.5 \mathrm{kBq}(2.5$ $\mu \mathrm{Ci}{ }^{65} \mathrm{Zn}$.

The retention at zero time of ${ }^{65} \mathrm{Zn}$ was corrected to allow for endogenous loss so that true $\mathrm{Zn}$ absorption could be calculated. The healthy volunteers absorbed (mean \pm SD) $32.5+12.4 \%$ of the dose whereas five untreated patients absorbed $30.4 \pm 14.5 \%$. This difference was not significant. Two partially-treated patients absorbed $30 \cdot 8+4 \cdot 2 \%$.

The biological whole body half-life was calculated over the period ro-6o d post administration. The half-life of intravenously-injected ${ }^{65} \mathrm{Zn}$ in the healthy volunteers was $219.0 \pm 21.8 \mathrm{~d}$ whilst in the untreated coeliacs it was $150.0 \pm 12.5 \mathrm{~d}$ $(P<0.001)$. Following the institution of a strict gluten-free diet 2 weeks after eating the labelled meal, the half-life improved to $235.8 \pm 85.5 \mathrm{~d}$ and was similar to that of the volunteers.

Contrary to our previous findings, this study has shown no difference in the true absorption of ${ }^{65} \mathrm{Zn}$ between untreated coeliacs and healthy volunteers. A possible reason is that we used a $5^{\circ} \mathrm{mg}$ dose of $\mathrm{Zn}$ in our earlier study but only $2 \mathrm{mg}$ in this study, so that the mucosal uptake mechanisms are less severely stressed. $\mathrm{Zn}$ absorption may also be occurring more distally where the mucosal changes are less marked. There is increased loss of $\mathrm{Zn}$ from the body as judged by whole-body turnover and this is reversed within 2 months of starting on a strict gluten-free diet.

P.J.A. and S.G. thank the Rank Prize Fund and the Medical Research Council respectively for financial support.

Crofton, R. W., Glover, S. C., Aggett, P. J., Mowat, N. A. G., Ewen, S. W. B. \& Mills, C. F. (1982). Proc. Nutr. Soc. 41, 7rA. 
Microbial metabolism of xenobiotics in vitro by caecal contents from rats given different diets. By A. WISE, Medical Research Council Laboratories, Carshalton, Surrey $S_{5}{ }_{4} E F$ and I. R. Rowland and A. K. Mallett, British Industrial Biological Research Association, Carshalton, Surrey $S M_{5} 4 D S$

Groups of six male, Sprague-Dawley rats were given diets containing one of ten components that are known to be poorly digested or indigestible. They were given at a concentration of $50 \mathrm{~g} / \mathrm{kg}$ in a purified diet, as described previously for an experiment in which pectin was the only compound studied (Wise et al. 1982). After 4 weeks the activities of five microbial enzymes ( $\mu \mathrm{mol} / \mathrm{h}$ per caecum) were measured anaerobically: azoreductase (AZ); beta-glucosidase (GS); betaglucuronidase (GR); nitroreductase (NO); and nitrate reductase (NA). The methods were as described by Wise et al. (1982) and Rowland et al. (1983). GS could not be determined for Maillard product (heated glucose and glycine) because it was highly coloured. Median weights of caecal contents (CC;g), bacterial numbers (BA $\times{ }_{10}{ }^{11}$ determined by direct microscopic clump counts) and enzyme activities were tested for significance $(P<0.05)$ by the Mann Whitney $U$ test and expressed in the Table as ratios to the control values.

Ratio experimental:control

\begin{tabular}{|c|c|c|c|c|c|c|c|}
\hline & $\mathrm{CC}$ & BA & $A Z$ & GS & GR & NO & NA \\
\hline $\begin{array}{l}\text { Carboxymethyl } \\
\text { cellulose }\end{array}$ & $4 \cdot 8^{\bullet}$ & $3.6^{\circ}$ & $2.3^{\circ}$ & $8 \cdot 0^{\circ}$ & $2 \cdot 9^{\circ}$ & I. $5^{\circ}$ & $4 \cdot 5^{\circ}$ \\
\hline Guar gum & $2.0^{\circ}$ & $2 \cdot 3^{\circ}$ & $3 \cdot 1^{\circ}$ & $4 \cdot 2^{\circ}$ & $2 \cdot 3^{\circ}$ & $1 \cdot 3^{\circ}$ & $\begin{array}{l}4.5 \\
2.5^{\circ}\end{array}$ \\
\hline Locust bean gum & $1 \cdot 9$ & 1.6 & $2 \cdot 1 *$ & $2 \cdot 8^{\circ}$ & 1.8 & 1.8 & $2.9^{\circ}$ \\
\hline Gum acacia & $2 \cdot I^{*}$ & $1 \cdot 3$ & $2 \cdot 5^{\circ}$ & $1 \cdot 3$ & $I \cdot 4$ & I. $3^{\circ}$ & $3.8^{\circ}$ \\
\hline Sorbitol & $2 \cdot I^{\star}$ & $2.9^{\circ}$ & $2 \cdot 5^{\circ}$ & 3.4 & 2.6 & I. 5 & 0.4 \\
\hline Pectin & $2 \cdot 3^{*}$ & $2 \cdot 5^{*}$ & 1.8 & I. 2 & $1 \cdot 4$ & $1 \cdot 2$ & $7.8^{\bullet}$ \\
\hline Maillard product & $3 \cdot I^{*}$ & I. 5 & 0.9 & ND & I. 8 & I. 2 & $1 \cdot 6^{\circ}$ \\
\hline Raw potato starch & I. 6 & $1 \cdot 9$ & 0.8 & 0.9 & $1 \cdot 1$ & 0.8 & I. I \\
\hline Agar agar & I. $7^{*}$ & 0.7 & 0.3 & $0.4^{\circ}$ & $0.2^{*}$ & $0.1^{*}$ & 0.7 \\
\hline arragheenan & $1 \cdot 7^{\circ}$ & $0.02 *$ & $0.04^{\circ}$ & $0.07^{\circ}$ & $0.03^{\circ}$ & $0.01^{\circ}$ & $0.13^{\circ}$ \\
\hline Control values & $1 \cdot 7$ & 1.4 & 47 & 15 & 14 & I. 1 & I I \\
\hline
\end{tabular}

ND, not determined, $\bullet P<0 \cdot 05$.

It was concluded that dietary components that are poorly digested by mammalian enzymes influence caecal microbial enzyme activities. As observed previously, pectin increased specifically NA activity (Wise et al. 1982).

Rats given carboxymethyl cellulose had the highest caecal enzyme activities and carragheenan-fed animals the lowest. In both cases the activities were related to bacterial numbers. The dietary components are ranked in the Table according to their ability to increase caecal microbial enzyme activities.

Rowland, I. R., Wise, A. \& Mallett, A. K. (1983). Food Chem. Toxicol $21,25$.

Wise, A., Mallett, A. K. \& Rowland, I. R. (I982). Xenobiotica 12, I II. 
The influence of obesity on bile acid and neutral sterol excretion with special reference to cholesterol metabolism. By M. S. Sian, Professorial Department of Surgery, Charing Cross Hospital Medical School, London W6 $8 R F$

Obesity is associated with an increased incidence of cholesterol-gallstone disease. It is believed that cholesterol-gallstone formation occurs when there is an excessive amount of cholesterol in bile relative to the amounts of bile acids and phospholipids (Sian \& Rains, 1979). The sources of excessive amounts of cholesterol in bile may be either dietary or as a result of increased synthesis. The excessive accumulation of cholesterol in the body is prevented by its excretion in the faeces as neutral sterols and bile acids.

Bile acids are formed in the liver from cholesterol, and the daily excretion of bile acids and neutral sterols in the steady-state represents the daily rate of cholesterol synthesis (Grundy et al. 1965). This study was undertaken to investigate bile acid and neutral sterol excretion in 'overweight' and 'normal weight' subjects.

Bile acid and neutral sterol excretion was measured in four groups of subjects (mean values \pm SD). Overweight groups: six females and two males (age $30 \pm 5$ years and weight $92 \pm 19 \mathrm{~kg}$, i.e. $42 \%$ overweight). Normal weight group: six females and two males (age $28 \pm 5$ years and weight $62 \pm 3 \mathrm{~kg}$ ). Normal weight men: five men (age $27 \pm 3$ years and weight $62 \pm 4 \mathrm{~kg}$ ). Normal weight women: five women (age $25 \pm 3$ and weight $63 \pm 3 \mathrm{~kg}$ ). Total 3 -d stools were collected and stored at $-20^{\circ}$ until analysed. Gas chromatography was used for analyses and the ideal body-weight of each subject was derived from standard tables (Metropolitan Life Insurance Co., 1959).

Total bile acid and neutral sterol excretion $(\mathrm{mg} / \mathrm{d})$ in the overweight group was significantly higher than that in the normal group (I $444 \pm 178, n 8 v .698 \pm 97, n 8$; $P<0.001$ ). Since the incidence of gallstone disease is higher in women, the bile acid excretions in men and women were compared. Bile acid and neutral sterol excretion in women was lower than that in men $\left(638 \pm 90, n_{5} v .840 \pm 68, n 5\right)$ but the difference was lost when the excretion was expressed in $\mathrm{mg} / \mathrm{kg}$ per $\mathrm{d}(\mathrm{r} 0 \cdot 2 \pm \mathrm{I} \cdot 7$ ข. 13.3 $\pm 1 \cdot 3$ ). Qualitatively, bile acids and neutral sterols in the four groups were similar.

The higher excretion of bile acids and neutral sterols in the overweight group supports the idea of a higher synthesis of cholesterol in the liver in these subjects. This suggests that there is a higher level of steady-state synthesis and excretion of cholesterol in the overweight subjects. The significance of this and its relationship to supersaturation of bile needs further investigation.

Grundy, S. M., Ahrens, E. H. \& Miettinen, M. (1965). 7. Lipid Res. 6, 397.

Metropolitan Life Insurance Co. (1959). Statist. Bull. 40, I.

Sian, M. S. \& Rains, A. J. H. (1979). Clin. Chim. Acta 98, 243. 
Dietary magnesium reduces nephrocalcinosis and kidney adenylate cyclase (EC 4.6.1.1) activity in rats. By SHOKOUFEH MERAJi, K. Richard Bruckdorfer and John Yudkin, Department of Nutrition, Queen Elizabeth College, University of London, London $W 8{ }_{7 A H}$ and -Department of Biochemistry and Chemistry, School of Medicine, Royal Free Hospital, London $\mathrm{NW}_{3}$

Rats given a semi-purified diet readily develop nephrocalcinosis within a few weeks. This may be alleviated if the amount of magnesium in the diet is increased (Heaton \& Anderson, 1965).

The pathogenesis of nephrocalcinosis and the mode of action of $\mathrm{Mg}$ are not fully understood. One suggestion is that parathyroid hormone is involved, increasing the activity of adenylate cyclase $(E C$ 4.6.1.1) in the kidney cortex and the concentration of intracellular calcium (Chase \& Aurbach, 1967; Kurokawa, 1977). Female rats are more susceptible to nephrocalcinosis than male rats, and diets with sucrose have been reported to produce more nephrocalcinosis in male rats than do diets with starch (Kang et al. 1979).

Four groups of female Wistar rats ( $180-230 \mathrm{~g})$ were given diets containing $(\mathrm{g} / \mathrm{kg}$ diet) either starch or sucrose $55^{\circ}$, butter 200 , casein 160 , cellulose 30 , minerals 40 and vitamins 20 (Kang et al. 1979) plus either 500 or $2500 \mathrm{mg} \mathrm{Mg} / \mathrm{kg}$ diet. In this experiment, no differences in calcification were found between the groups given diets with starch or with sucrose, and the higher quantity of $\mathrm{Mg}$ reduced calcification equally with both diets.

In the second experiment, only diets with sucrose were given to three groups of twelve rats which received either 50,500 or $2500 \mathrm{mg} \mathrm{Mg} / \mathrm{kg}$ diet. The basal activity of adenylate cyclase (Krishna et al. 1968) in kidney cortex plasma membranes was found to be progressively decreased with the increasing dietary Mg (see Table).

Adenylate cyclase activity in renal cortex plasma membranes in rats (pmol cyclic AMP/mg per $20 \mathrm{~min}$ )

$\mathrm{Mg}$ in $\operatorname{diet}(\mathrm{mg} / \mathrm{kg}) \ldots$
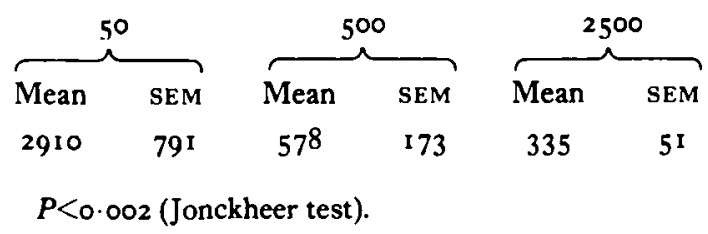

These results are consistent with the known effect of parathyroid hormone on adenylate cyclase activity and supports the suggestion that the parathyroid hormone is involved in causing nephrocalcinosis.

We wish to thank Dr J. R. Mason for help and advice with the enzyme assays.

Chase, L. R. \& Aurbach, G. D. (1967). Proc. natn. Acad. Sci. USA 58, 518.

Heaton, F. W. \& Anderson, C. K. (1965). Clin. Sci. 28, 99.

Kang, S. S., Price, R. G., Yudkin, J., Worcester, N. A. \& Bruckdorfer, K. R. (1979). Br. F. Nutr. 41, 65 .

Krishna, G., Weiss, B. \& Bordie, B. B. (1968). F. Pharm. Exp. Therap. 163, 379.

Kurokawa, K. (1977). Adv. exp. Med. Biol. 81, 291. 
Erythropoiesis and red cell life span in riboflavin-deficient rats. By

C. J. Port and D. I. Thurnham, Department of Human Nutrition, London School of Hygiene and Tropical Medicine, London $W C_{1} E_{7} H T$

Studies on riboflavin-deficient rats suggested a reduction in erythropoiesis and an increase in mean red blood cell (RBC) age (Hassan \& Thurnham, 1977). Studies on marginally riboflavin-deficient human subjects, however, indicated an increase in erythropoiesis (Powers \& Thurnham, 1980). In an attempt to resolve these differences, radioactive iron $\left({ }^{59} \mathrm{Fe}\right)$ was used to measure $\mathrm{RBC}$ life span in riboflavin-deficient rats.

Wistar rats (approximately $50 \mathrm{~g}$ ) were divided into control, weight-matched, pair-fed, and deficient groups. Weight-matched animals were obtained by restricting food intake. After $\mathrm{I}_{4} \mathrm{~d}$ the method of McKee et al. (I g68) was used to label $\mathrm{RBC}$ (citrate- ${ }^{59} \mathrm{Fe}$, $10 \mu \mathrm{Ci} / \mathrm{I} 00 \mathrm{~g}$ body-weight, injected intraperitoneally (i.p.)). Reutilization of ${ }^{59} \mathrm{Fe}$ was reduced by giving an iron-dextran solution (Imferon, $5 \mathrm{mg} / \mathrm{ro0} \mathrm{g}$ body-weight, i.p.) every $2 \mathrm{~d}$ from the $4^{\text {th }}$ day. The mean ( \pm SEM) RBC glutathione reductase $(E C$ I.6.4.2) activation coefficient of deficient groups in one experiment was $2.35(0.09)$ at day 35 . The extent of riboflavin deficiency was similar in both experiments.

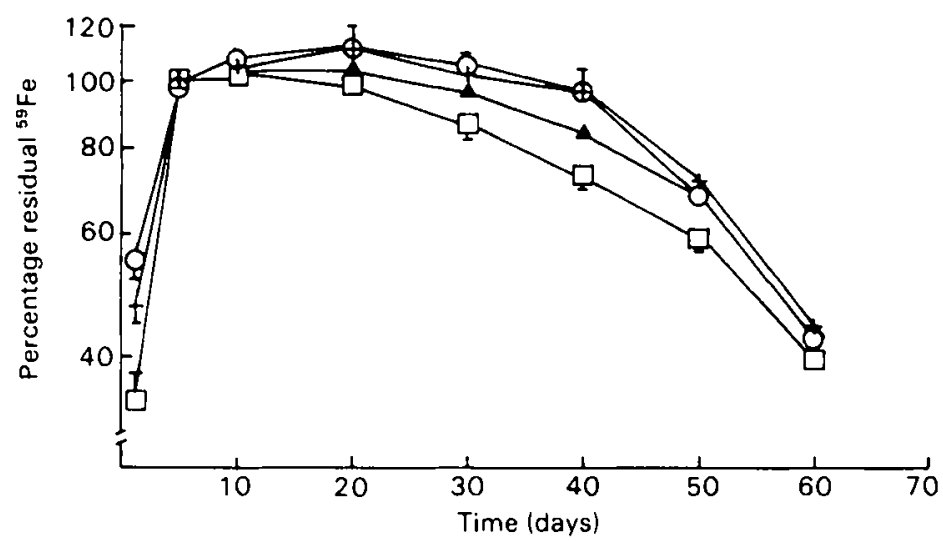

Median (+ SE) life span for the following groups: $O$, control $57 \cdot 4(\mathbf{I} \cdot 5 \mathrm{I})$; +, pair-fed $59 \cdot 8(2 \cdot 25)$; $\Delta$, weight-matched $69 \cdot 0(7 \cdot 35) ; \square$, deficient $57 \cdot 1(4 \cdot 30)$.

The rate of RBC destruction was similar for each group but it began much earlier in the deficient animals. The Figure shows a semilog plot of percentage residual $\mathrm{Fe}$ against time and values for median life span for all groups. The median RBC life span in riboflavin deficiency was not significantly different from that of control groups but, to compensate for the earlier RBC destruction, erythropoiesis may be slightly increased.

We wish to thank the Department of Health and Social Security for some financial support. 
Methodology of folic acid assay in foods. By N. I. NiK-DaUd and A. E.

BENDER, Department of Nutrition, Queen Elizabeth College, University of London, London $\mathrm{W}_{7} \mathrm{AH}$

Many of the earlier assays of folic acid are not reliable because the method requires rigid control of several factors which were not recognized at the time. Current procedures have been successfully applied to blood (Chanarin et al. 1972) but have not, so far, been extended to foods. The method depends on the growth response of Lactobacillus casei to a phosphate-buffer extract of the vitamin. This organism responds only to 'free folate' (three or fewer glutamate residues) and the assay of total folate requires a preliminary treatment with a conjugase enzyme system to liberate the free form.

The method requires control of a number of variables, especially when applied to foods.

(1) The inoculum must be of constant size and growth phase and this has been achieved by storing the harvested inoculum at low temperatures; i.e. $21 \mathrm{~d}$ at $-20^{\circ}$, $90 \mathrm{~d}$ at $-60^{\circ}$ and at least $\mathrm{r} 0$ months in liquid nitrogen.

(2) The problem of maintaining sterility during the $16 \mathrm{~h}$ treatment of extracts with the conjugase (Jagerstad et al. 1975) and the $24 \mathrm{~h}$ of assay has been overcome by the use of a chloramphenicol-resistant strain. The addition of the antibiotic in amounts adequate to maintain sterility (100 and $10 \mu \mathrm{g} / \mathrm{ml}$ sample extract and assay medium respectively) does not affect the growth of the organism nor the values obtained.

(3) It has been established that not less than $100 \mathrm{mg}$ ascorbic acid added to the phosphate buffer used in the extraction, and also to the assay medium, protects the folate and $250 \mathrm{mg} / 100 \mathrm{ml}$ is recommended to provide a margin of safety.

(4) It has been confirmed that the optimum $\mathrm{pH}$ for the action of purified chicken pancreas conjugase needed to liberate free folate lies between $\mathrm{pH} 7$ and 8 , since its activity is reduced by approximately $20 \%$ if the $\mathrm{pH}$ falls to 6.5 or rises above 8.5 .

Chanarin, I., Kyle, R. \& Stacey, J. (1972). F. clin. Path. 25, 1050.

Jagerstad, M., Lindstraad, K. \& Westesson, A. K. (1975). Scand. F. Soc. Med. ro Suppl., 78 . 
The content and stability of folic acid in foods. By N. I. NIK-DAuD and A. E. Bender, Department of Nutrition, Queen Elizabeth College, University of London, London $W 87 A H$

The adequacy of folic acid intake is uncertain (Ebrahim, 1979) and it is reported that much of the folic acid in foods is unstable during processing and cooking and may even be lost during storage at room temperature (Briggs \& Calloway, I979; Pfeiffer, 1982). However, there is little reliable information available on the folate content of foods and reports of its instability may be due to errors in methodology of assay.

Analysis of a number of vegetable foods, a major source of folate, indicates that it is stable to heat although, being water-soluble, a proportion can be extracted into the water used in processing and cooking.

Folic acid cannot be completely extracted from raw vegetables and they require a preliminary autoclaving; the amount of total folate extracted from homogenized raw lettuce was less than half the cotal present (Table r). Similarly, without preliminary autoclaving only $70 \%$ of the total folate was extracted from red peppers and $83 \%$ from green cabbage.

Table I. Total folate in lettuce (Lactuca sativa) $(\mu \mathrm{g} / \mathrm{kg})$

\begin{tabular}{|c|c|c|c|}
\hline \multirow[b]{2}{*}{ Raw } & \multicolumn{3}{|c|}{ Autoclaved $5 \mathrm{~min}$ at pressures $\left(\mathrm{N} / \mathrm{m}^{2}\right)$ of } \\
\hline & $3.45^{\times} \times 10^{4}\left(108^{\circ}\right)$ & $6.89 \times 10^{4}\left(115.3^{\circ}\right)$ & $1.03 \times 10^{5}\left(121^{\circ}\right)$ \\
\hline 330 & 670 & 680 & 680 \\
\hline
\end{tabular}

Autoclaving does not appear to be destructive to any significant extent (for 5 min at $3.45 \times 10^{4} \mathrm{~N} / \mathrm{m}^{2}$ ) since heating at higher temperatures does not reduce the amount of folate found (Table $\mathrm{r}$ ).

Table 2 shows the initial folate value in $\mu \mathrm{g} / \mathrm{kg}$ (column $\mathrm{A}$ ) and the percentage left in the food after $20 \mathrm{~min}$ boiling (column B) together with the percentage in the water (column C). There was no destruction of folate.

Table 2.

\begin{tabular}{|c|c|c|c|c|c|c|c|c|c|c|c|}
\hline \multicolumn{3}{|c|}{ Chinese leaves } & \multicolumn{3}{|c|}{ Green cabbage } & \multicolumn{3}{|c|}{ French beans } & \multicolumn{3}{|c|}{ Brussels sprouts } \\
\hline$A$ & B & $\widehat{C}$ & $\mathbf{A}$ & B & $\overrightarrow{\mathrm{C}}$ & $\mathrm{A}$ & B & C & A & B & C \\
\hline 980 & 62 & 27 & 590 & $5^{6}$ & $4 I$ & 740 & 68 & 30 & $174^{\circ}$ & 64 & 40 \\
\hline
\end{tabular}

Briggs, G. M. \& Calloway, D. H. (1979). In Bogart's Nutrition and Physical Fitness, roth ed., p. 20r. New York: W. B. Saunders Co.

Ebrahim, G. J. (1979). In Nutrition and Disease, p. 125 [R. J. Jarrett, editor]. London: Croom Helm.

Pfeiffer, C. C. (1982). In Nutrition and Killer Diseases [J. Rose, editor]. New Jersey: Noyes Publications. 
$A$ new guar bread: an effective hypocholesterolaemic agent in patients with hypercholesterolaemia? By Patricia A. JUDD, A. R. LEEDS and J. A. A. Gooch, Department of Nutrition, Queen Elizabeth College, Campden Hill Road, London $W 87 A H$ and P. R. Ellis, Department of Food Science, University of Reading, London Road, Reading $R G$ I $5 A G$ and E. W. JEPSON, Willesden General Hospital, Harlesden Road, London $N W_{1} 0_{3} R Y$

Guar gum, a viscous unabsorbable polysaccharide, is hypocholesterolaemic in normal and hyperlipidaemic subjects but its usefulness has been restricted by its physical properties, which limit the daily dose.

A bread with $10 \%$ of the dry ingredients replaced by guar gum was prepared (Apling et al. 1978). After stabilizing body-weight and blood lipids with reducingand low-fat-diets, at least $\mathrm{I} 20 \mathrm{~g}$ of a white 'control' bread was incorporated into the daily diets of four female and two male patients. After I month, the control bread was substituted by guar bread, differing only in containing $5.9 \mathrm{~g}$ guar $\mathrm{gum} / \mathrm{100} \mathrm{g}$ and having a higher water content, and this was taken for a further month.

Daily records of food intake and gastrointestinal side effects were kept for the whole period. Venous blood samples were taken after an overnight fast at the beginning and end of each month. Total plasma cholesterol and HDL cholesterol (after treatment of plasma with manganese chloride and heparin (Warnick \& Albers, 1978)) were measured by an enzymic method (Roschlau, 1975).

Liver function tests and haematological indices were measured in the routine hospital laboratory.

Bread intake ranged from 120 to $290 \mathrm{~g} / \mathrm{d}$, guar intake thus being 7-1 $8 \mathrm{~g} / \mathrm{d}$ (mean $12 \mathrm{~g})$. There were no significant changes in weight, liver function tests or haemoglobin levels, and gastrointestinal side effects were not a problem.

Plasma total cholesterol levels were reduced in three subjects, but the mean fall of $5 \%$ was not statistically significant. HDL cholesterol levels were unchanged.

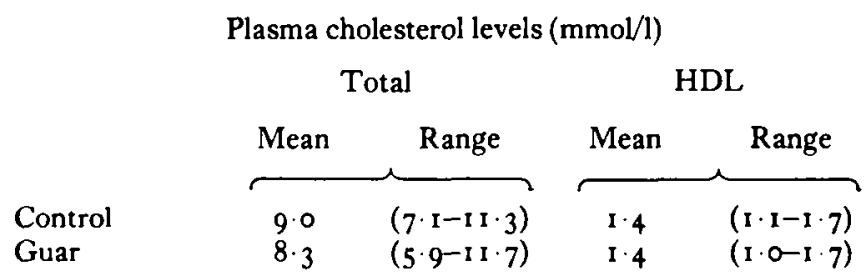

These preliminary results suggest that the guar bread may be an effective hypocholesterolaemic agent in some individuals. However, the dose which can be taken in this form may be at the lower end of the dose-response curve; the development of other guar-containing foods is therefore indicated.

We are grateful to John Ajodhia, Leo Reynolds, Norman Bolster, David Lincoln, Sister Kowalcyzk, Mrs. Fennecke Outon and Dr. P. Apling for invaluable assistance and to Drs Brozovic and Frost for routine analysis of blood samples.

Apling, E. C., Kahn, P. \& Ellis, P. R. (1978). Cereal Fds Wld. 23, 640.

Roschlau, P. (1975). Ninth International Congress on Clinical Pathology, Toronto.

Warnick, G. R. \& Albers, J. J. (1978). F. Lipid Res. 19, 65. 